Care: Jurnal Ilmiah Ilmu Kesehatan Vol .7, No.1,2019,hal 9-18

Tersedia online di https://jurnal.unitri.ac.id/index.php/care

ISSN 2527-8487 (online)

ISSN 2089-4503 (cetak)

\title{
Kombinasi Glucomannan Hydrolysates (Gmh) Dan Antibiotik Metronidazole Berpengaruh Terhadap Kadar Sitokin Il-23 Pada Bacterial Vaginosis Wanita Usia Subur
}

\author{
Anik Sri Purwanti ${ }^{1}$, Sumarno ${ }^{2}$, Bambang Rahardjo ${ }^{3}$, Sri Winasih ${ }^{4}$, Sri Poeranto ${ }^{5}$ \\ ${ }^{1}$ Magister Kebidanan Fakultas Kedokteran Universitas Brawijaya Malang \\ ${ }^{2}$ Departemen Mikrobiologi Fakultas Kedokteran Universitas Brawijaya \\ ${ }^{3}$ Departemen Obstetri dan Ginekologi Rumah Sakit dr. Saiful Anwar Malang \\ ${ }^{4}$ Departemen Mikrobiologi Klinik Fakultas Kedokteran Universitas Brawijaya \\ ${ }^{5}$ Departemen Parasitologi Fakultas Kedokteran Universitas Brawijaya \\ e-mail: nicksetiawan2601@gmail.com
}

\begin{abstract}
Woman's reproductive tract often has problems, especially in women of childbearing age. One of them is Bacterial Vaginosis is a clinical condition that occurs a lot. BV infection is a polymicrobial infection caused by a decrease in the amount of Lactobaclilus with anaerobic bacteria that increases excessively. Alternative treatment for $B V$ is given by using the results bydrolysates of konjac plant extracted in dosage forms Glucomannan Hydrolysates (GMH) containing glucose and mannose prebiotic which can support the growth development of Lactobacillus in the vaginal mucosa. This study was to determine the effect of Glucomannan Hydrolisates $(G M H)+$ Metronidazole on levels of IL 23 cytokines in BV of reproductive age women. The method of this study used the True Experimental design with the type of research The randomized pretestposttest was in vivo. The subjects selected in this study design used Randomized techniques. A sample of 7 people WUS with BV given GMH 300mg + Metronidazole $1000 \mathrm{mg}$ for 9 days of use, To assess the levels of cytokine IL 23 using the ELIS A method. Data analysis using a ratio scale was analyzed using the metric statistical test, normality test using Shapiro-Wilk test and comparative test using Repeated Measure ANOVA. The overall results of the analysis showed that the combination of GMH and Antibiotics Metronidazole could significantly increase the levels of cytokine IL 23 compared to other therapies to treat bacterial vaginosis in women of childbearing age.
\end{abstract}

Keyword: Bacterial Vaginosis (BV); Glucomannan Hydrolysates (GMH); IL-23 levels

\begin{abstract}
ABSTRAK
Saluran reproduksi wanita sering kali mengalami masalah, terutama pada wanita usia subur. Salah satunya yaitu Bakterial Vaginosis merupakan suatu kondisi klinis yang banyak terjadi. Infeksi BV merupakan infeksi polimikrobial disebabkan oleh penurunan jumlah Lactobaclilus disertai bakteri anaerob yang meningkat secara berlebihan. Lactobacillus merupakan bakteri dominan yang berperan sebagai regulator flora normal didalam vagina. Dimana ketidakseimbangan flora normal mengakibatkan adanya suasana abnormal, ditandai dengan perubahan konsentrasi hidrogen peroksida $\left(\mathrm{H}_{2} \mathrm{O}_{2}\right)$. Penurunan konsentrasi $\mathrm{H}_{2} \mathrm{O}_{2}$ ini akan digantikan oleh meningkatnya konsentrasi bakteri anaerob salah satunya Gardnerella vaginalis sehingga terjadilah BV. Untuk mengatasi BV diberikan terapi alternative menggunakan hasil
\end{abstract}

Cara mengutip: Purwanti,AS., Sumarno, Rahardjo,B., Winasih,S.,Poeranto,S.(2019). Kombinasi Glucomannan Hydrolysates (Gmh) Dan Antibiotik Metronidazole Berpengaruh Terhadap Kadar Sitokin Il-23 Pada Bacterial Vaginosis Wanita Usia Subur. Care:Jurnal Ilmiah Ilmu Kesehatan, 7(1), 9-18 Retrieved from https://jurnal.unitri.ac.id/index.php/care/article/view/1105 
dari hidrolisat tanaman konjac yang telah diextraksi dalam bentuk sediaan Glucomannan Hydrolysates $(\mathrm{GMH})$ mengandung prebiotic glucose dan mannose yang dapat mendukung pertumbuhan dan perkembangan Lactobacillus di mukosa vagina. Penelitian ini untuk mengetahui pengaruh Glucomannan Hydrolisates $(G M H)$ + Antibiotik Metronidazole terhadap kadar sitokin IL 23 pada $B V$ wanita usia subur. Metode penelitian ini menggunakan rancangan True Experimental dengan jenis penelitiannya The randomized pretest-posttest secara in vivo. Subjek yang dipilih pada rancangan penelitian ini menggunakan teknik Randomized. Sampel sebanyak 7 orang WUS dengan BV yang diberikan GMH 300mg + Metronidazole 1000mg selama 9 hari penggunaan, Untuk menilai kadar sitokin IL 23 menggunakan metode ELISA. Analisa data menggunakan skala rasio dianalisis menggunakan uji statistik para metric, uji normalitas menggunakan uji Shapiro-Wilk dan uji komparasi menggunakan Repeated Measure $A N O V A$. Hasil analisis secara keseluruhan menunjukkan pemberian kombinasi GMH dan Antibiotik Metronidazole dapat meningkatkan kadar sitokin IL 23 secara signifikan dibandingkan dengan terapi lain untuk mengatasi Bacterial Vaginosis pada wanita usia subur.

Kata Kunci: Bacterial Vaginosis (BV); Glucomannan Hydrolysates (GMH); Kadar IL-23

\section{PENDAHULUAN}

Masalah pada saluran reproduksi sering dialami oleh wanita terutama pada usia subur. Salah satunya yaitu Bakterial $V$ aginosis atau yang biasa disingkat dengan $\mathrm{BV}$, yang merupakan suatu kondisi klinis yang banyak terjadi pada wanita, terutama pada usia reproduksi (Patterson, StullLane, Girerd, \& Jefferson, 2010). Pada mulanya BV disebut vaginitis yang nonspesifik, yaitu suatu keadaan yang menjadi pengecualian dari vaginitis yang sudah jelas etiologinya.

Angka kejadian BV di Amerika mendapatkan prevalensi BV sebesar $25 \%$, $50 \%$ diantaranya asimtomatis (Hay, 2014). Di Indonesia tidak kalah jumlahnya dari prevalensi di dunia. Di RSUD dr. Soetomo Surabaya mengalami peningkatan prevalensi selama tahun 2011-2013 yaitu BV 45\%-50\%, Vulvovaginal Kandidiasis 30\%-35\% dan Trichomoniasis 5\%-10\%.

Infeksi BV adalah jenis polimikrobial disebabkan oleh menurunnya jumlah Lactobaclilus dikuti jumlah bakteri anaerob yang meningkat secara berlebihan. Lactobacillus adalah bakteri dominan didalam vagina wanita, berperan sebagai regulator flora normal. Ketidakseimbangan flora normal inilah yang dapat mengakibatkan terjadinya suasana yang abnormal ditandai dengan perubahan konsentrasi $\mathrm{H}_{2} \mathrm{O}_{2}$ yang merupakan hasil dari produksi Lactobacillus di vagina. Penurunan konsentrasi $\mathrm{H}_{2} \mathrm{O}_{2}$ ini akan digantikan oleh meningkatnya konsentrasi bakteri anaerob salah satunya Gardnerella 
vaginalis. Dimana G.Vaginalis sebanyak 95\% muncul pada kasus BV (Patterson et al., 2010)

Faktor resiko yang dapat mendukung terjadinya BV antara lain wanita yang memiliki banyak pasangan atau bergantiganti pasangan seksual, penggunaan $\mathrm{KB}$ IUD, antibiotik, bilas vagina (douching) dan merokok. Akibatnya paparan BV pada WUS dapat memperparah infeksi saluran genital, endometritis, infeksi pascaoperasi, dan infeksi saluran (Ness RB, Soper DE, Holley RL, 2001)(Guaschino S, De Santo D, 2002), meningkatkan resiko penyakit PID, serta meningkatkan risiko komplikasi pada penyakit menular seksual (Fethers K, Twin J, Fairley Ck, Fowkes Fj, Garland Sm, Fehler G, 2012) dan HIV (Thurman et al., 2015), maupun infeksi penyakit kelamin lainnya (CDC, 2017).

Patterson et al. (2010) menunjukkan bahwa G. vaginalis mampu membentuk biofilm yang menempel pada epitel vagina wanita dengan BV. Biofilm tersebut dapat memfasilitasi kelompok bakteri lain untuk ikut masuk ke dalam lapisan. Hal tersebut dapat menunjukkan bahwa ada kemungkinan untuk bakteri anaerob lain ikut menginvasi vagina. G. vaginalis juga memproduksi vaginolysin toxin, yang merupakan anggota dari family Cholesterol-
Dependent Cytolysin (CDC), toxin ini lisis dalam sel darah merah manusia dan sel-sel epitel (Patterson et al., 2010). Kemudian vaginolysin toxin akan dikenali oleh Antigen Precenting Cell (APC). APC akan mengeluarkan sitokin - sitokin sebagai pemicu aktivasi $\mathrm{T}$ naive membentuk Th1, Th2, Treg dan Th 17. Salah satu sitokin yang dikeluarkan oleh APC adalah Interleukin - 23 (IL 23) yang membuat $\mathrm{T}$ naïve berdiferensiasi menjadi Th17 yang kemudian mengeluarkan IL17 dan IL 22. Dimana IL 23 yang dihasilkan oleh APC memiliki kemampuan untuk meningkatkan sel $\mathrm{T}$ memproduksi IFN $\gamma$ dan proliferasi sel T. IL 22 sebagai hasil dari sekresi Th 17 yang memiliki penting dalam modulasi respon jaringan selama terjadi inflamasi (Zheng, Yan., Dimitry M., Danilenko., Patricia Valdez., Ian Kasman., Jeffrey Eastham-Anderson., 2007) serta mempertahankan host dari paparan penyakit autoimun dari paparan bakteri pathogen ekstraseluler (Leung et al., 2010).

Umumnya penderita BV akan diberikan terapi berupa antibiotik Metronidazole dan Clindamycin dalam formulasi oral atau topikal (Workowski \& Levine, 2002). Namun, pemberian antibiotik tersebut kurang memuaskan, tidak mampu mencapai lebih dari sekitar 70\% dari angka kesembuhan (J, 2004), dan apabila 
pemberian antibiotik secara terus menerus dapat menimbulkan efek resistensi sehingga tak jarang dapat meningkatkan kejadian berulang. Selain itu, pemberian antibiotic pada BV dapat memberikan efek negatif terhadap pertumbuhan dan perkembangan microflora normal yang ada didalam vagina (Machado, Castro, Palmeira-de-Oliveira, Martinez-deOliveira, \& Cerca, 2016). Maka perlu adanya suatu metode baru guna memerangi paparan dari BV. Salah satunya yaitu dengan pemberian prebiotic dan probiotik untuk menstimulasi pertumbuhan bakteri menguntungkan (Machado et al., 2016). Salah satu prebiotic yang dapat manfaatkan sebagai alternative penanganan BV yaitu Glucomannan Hydrolysates $(G M H)$. Pada GMH mengandung berbagai nutrisi yang dibutuhkan untuk pertumbuhan dan perkembangan flora normal vagina. GMH merupakan hasil ekstraksi (sebagai polisakarida) dari tanaman Konjac yang banyak digunakan di Asia sebagai sumber pangan (Tester \& Al-Ghazzewi, 2013), diperoleh dari teknik hidrolisis polisakarida glukomannan dari tanaman konjac. Material prebiotic ini telah teruji baik secara in vitro maupun in vivo dan berhasil yang ditunjukkan dengan peningkatan pertumbuhan Lactobacilli) Bifidobacteria (Tester \& Al-Ghazzewi,
2013), dan berkurangnya pathogen (Sutherland, 2008).

\section{METODE PENELITIAN}

\section{Responden}

Penelitian ini menggunakan 6 orang responden WUS yang menderita Bacterial Vaginosis, dengan kriteria inklusi Wanita usia 20-49 tahun, telah menikah atau sudah pernah berhubungan seksual, tidak berganti- ganti pasangan, siklus mestruasi yang teratur. Pada saat berpartisipasi dalam penelitian maksimal pada hari ke 7 setelah menstruasi. Mengalami keputihan encer, homogen dan berwarna putih keabu-abuan, hasil gram (+) bacterial vaginosis, $\mathrm{pH}$ vagina (> 4.5), terdapat "clue cells" pada pengujian dibawah mikroskop dari sampel swab vagina, adanya "fishy odor", bersedia menjadi responden penelitian dan telah disetujui oleh pasangan (suami). Seluruh responden diberikan intervensi berupa pemberian GMH dan Antibiotik sesuai jadwal pemberian. Dengan waktu 9 hari aplikasi intervensi dalam 22 hari lama observasi (H0-H22).

\section{Pengukuran Kadar Sitokin IL 23}

Sitokin IL 23 merupakan salah satu sitokin proinflamasi yang dikeluarkan oleh APC untuk memicu perkembangan sel $\mathrm{T}$ naïve CD4+ menjadi Th17 untuk memproduksi 
IL - 17, IL21, dan IL22 dimana apabila terjadi inflamasi maka kadar akan tinggi. Kadar sitokin ini dihitung dengan teknik ELISA menggunakan marker dari Biolegend Elisa $\mathrm{Max}^{\mathrm{TM}}$ Elisa Kit with Precoated Plates Human IL-23 Cat. No. 435407 (1 plates) Hasil pemeriksaan mengacu pada hasil pengukuran pada $\mathrm{H} 0$ (sebelum diberikan terapi) untuk kemudian dibandingkan dengan $\mathrm{H} 11$ dan H22 setelah intervensi. Skala yang digunakan adalah skala interval.

\section{Analisa Data}

Dalam penelitian ini analisa data menggunakan skala rasio dianalisis dengan menggunakan uji statistik para metric, kemudian uji normalitas menggunakan uji Shapiro-Wilk selanjutnya uji komparasi menggunakan Repeated Measure ANOVA

\section{HASIL}

\section{Karakteristik Usia Responden}

Usia responden yang ikut serta dalam penelitian ini direntang usia 20 - 49 tahun dengan total responden sebanyak 6 orang.

\section{Karakteristik Parietas Responden}

Dari 6 orang responden, 2 orang responden memiliki 1 orang anak (33,3\%), 3 orang responden memiliki 2 orang anak $(50 \%)$ dan hanya 1 orang responden yang memiliki 3 orang anak (16,7\%).

\section{Karakteristik Jenis Kontrasepsi}

Sebanyak 3 responden (50\%) yang tidak menggunakan alat bantu kontrasepsi, selain itu sebanyak 1 orang responden $(16,7 \%)$ sebagai akseptor kondom dan 2 orang responden (33,3\%) sebagai akseptor pil.

\section{Karakteristik Personal Hygiene}

Sebanyak 5 orang responden membersihkan area genetalia dengan menggunakan sabun (58\%), dan hanya sebanyak 1 orang responden yang menggunakan ramuan herbal (4\%) maupun menggunakan benda tertentu $(4 \%)$.

\section{Gambaran Karakteristik Bacterial Vaginosis Dalam Penelitian}

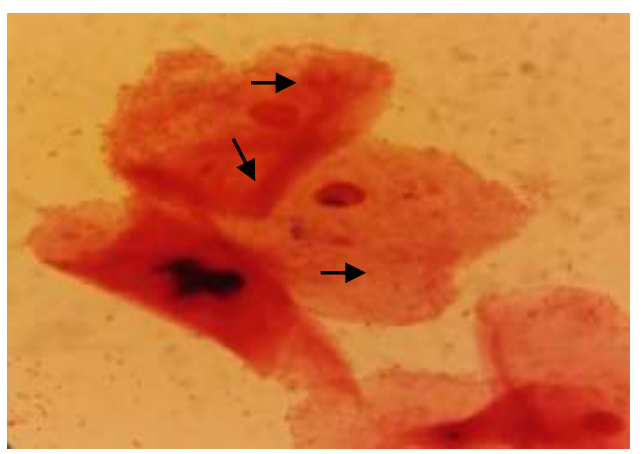

Gambar 1. Salah satu ciri terjadinya Bacterial Vaginosis (BV) adalah terdapat "clue cell".

Pemeriksaan mikroskopis gram staining menunjukkan sedikit peningkatan sel darah putih, koloni bakteri, hilangnya lactobacilli normal, dan karakteristik "clue cells" yang merupakan sel-sel epitel dengan 
berbagai bakteri pathogen yang menempel ke permukaan sel epitel.

\section{Hasil uji prasyarat parametrik}

Dalam penelitian ini hasil analisis data dengan skala rasio dianalisis dengan menggunakan uji statistik para metrik. Data kadar IL-23 bersakala rasio, sehingga perlu dilakukan uji prasyarat parametrik, yaitu data harus terbukti terdistribusi normal. Pada uji normalitas dilakukan dengan menggunakan uji Shapiro-Wilk. Adapun kriteria keputusan, yaitu bila nilai Sig atau p-value lebih besar dari taraf signifikansi $\propto=0.05$ maka data terdistribusi normal dan sebaliknya bila nilai Sig atau $p$-value lebih kecil dari taraf signifikansi $\propto=0.05$ maka data tidak terdistribusi normal. Pada analisis uji Shapiro-Wilk diperoleh dan dijelaskan secara lengkap tampak pada tabel di bawah ini.

Pada Tabel 1 berdasarkan hasil uji ShapiroWilk diperoleh bahwa data kadar IL-23 untuk masing- masing kelompok pengamatan menunjukkan nilai p-value yang semuanya terdistribusi normal yaitu lebih besar dari taraf signifikansi $\propto=0.05$. Oleh karena kadar IL-23 telah memenuhi uji prasyarat parametrik, yaitu data terbukti terdistribusi normal maka selanjutnya data siap diuji menggunakan uji Anova guna membuktikan hipotesa penelitian.

\section{Tabel 1. Hasil Uji Normalitas Data}

\begin{tabular}{lccc}
\hline Kelompok & Hari Pengamatan & $\mathrm{p}$-value & Distribusi \\
\cline { 3 - 3 } & & $\mathrm{IL}-23$ & \\
\hline GMH+AB & H0 & 0,688 & normal \\
& H11 & 0,325 & normal \\
& H22 & 0,345 & normal \\
\hline
\end{tabular}

Keterangan: Jika $p$-value $<0.05$ berarti data tidak terdistribusi normal dan jika $p$-value $>0.05$ maka data terdistribusi normal.

\section{Hasil uji perbandingan kadar IL-23 dengan pemberian GMH+Antibiotik Metronidazole}

Berdasarkan hasil uji One Way Anova pada data kadar IL-23 pada plasma darah wanita usia subur yang mengalami $B V$ yang diberi Glucomannan Hydrolysates (GMH)+ Antibiotik Metronidazole diperoleh ada perbedaan yang bermakna rerata pada sampel pengamatan, hal ini ditunjukkan dengan nilai p-value yang kurang dari $\propto=0.05$. Oleh karena ada perbedaan yang signifikan pada hasil uji One Way Anova maka dilanjutkan dengan uji Beda Nyata Terkecil/BNT (Least Significant Difference/LSD). Secara rinci ditunjukkan pada Tabel 2. 
Tabel 2. Perbandingan Antar Hari Pengamatan Pada Responden Dengan Pemberian GMH $+\mathrm{AB}$

\begin{tabular}{lcc}
\hline Hari & $\mathrm{n}$ & $\mathrm{IL}-23$ \\
\cline { 3 - 3 } pengamatan & $\mathrm{n}$ & Rerata $\pm \mathrm{SD}$ \\
\hline H0 & 6 & $7.93 \pm 0.15^{\mathrm{a}}$ \\
$\mathrm{H} 11$ & 6 & $8.19 \pm 0.02^{\mathrm{b}}$ \\
$\mathrm{H} 22$ & 6 & $8.24 \pm 0.01^{\mathrm{b}}$ \\
\hline p-value & & $0.000<\alpha$ \\
\hline
\end{tabular}

Keterangan:

Pada kolom rerata \pm sd memuat huruf yang menunjukkan hasil uji LSD, jika memuat huruf yang berbeda berarti ada perbedaan yang bermakna $(p$-value $<0.05)$ dan sebaliknya.

Pada Tabel 1 menunjukkan bahwa nilai rerata kadar IL-23 pada ketiga kelompok sampel tersebut ada perbedaan yang bermakna $(p=0.000<\propto)$. Tampak nilai rerata kadar IL-23 pada kelompok pengamatan hari $\mathrm{H} 0$ (sebelum perlakuan) $\left(7.93 \pm 0.15^{\mathrm{a}} \mathrm{pg} / \mathrm{mL}\right)$ dibandingkan dengan kelompok pengamatan $\mathrm{H} 11\left(8.19 \pm 0.02^{\mathrm{b}}\right.$ $\mathrm{pg} / \mathrm{mL}$ ) menunjukkan ada perbedaan yang bermakna. Demikian pula ada perbedaan yang bermakna rerata kadar IL-23 antara pengamatan hari $\mathrm{H} 0$ (sebelum perlakuan) $\left(7.93 \pm 0.15^{\mathrm{a}} \mathrm{pg} / \mathrm{mL}\right)$ dibandingkan dengan kelompok pengamatan $\mathrm{H} 22\left(8.24 \pm 0.01^{\mathrm{b}} \mathrm{pg} / \mathrm{mL}\right)$. Sedangkan rerata kadar IL-23 antara kelompok pengamatan H11 $\left(8.19 \pm 0.02^{\mathrm{b}}\right.$ $\mathrm{pg} / \mathrm{mL}$ ) dibandingkan dengan kelompok pengamatan $\mathrm{H} 22\left(8.24 \pm 0.01^{\mathrm{b}} \mathrm{pg} / \mathrm{mL}\right)$ menunjukkan tidak ada perbedaan yang bermakna. Berdasarkan nilai reratanya tampak terjadi peningkatan kadar IL-23 pada pengamatan H11 dan sedikit meningkat lagi pada pengamatan H22.

Pada Gambar 2 terlihat rerata histogram masih sedikit rendah pada awal pengamatan hari Ho perlakuan dibandingkan dengan kelompok yang lain, kemudian rerata kadar IL-23 sedikit meningkat pada pengamatan H11 selanjutnya meningkat lagi pada pengamatan H22. Tampak histogram tertinggi pada kelompok pengamatan $\mathrm{H} 22$ pada plasma darah wanita usia subur yang mengalami $B V$ yang diberi Glucomannan Hydrolysates $(\mathrm{GMH})+$ Antibiotik. Hal ini berarti bahwa pada darah wanita usia subur yang mengalami $B V$ yang diberi Glucomannan Hydrolysates $(\mathrm{GMH})+$ Antibiotik menunjukkan kadar IL-23 yang tinggi pada hari ke 22.Tampak peningkatan kadar sitokin IL-23 yang tampak bermakna pada pengamatan H11 namun tidak bermakna secara statistik pada $\mathrm{H} 22$ 


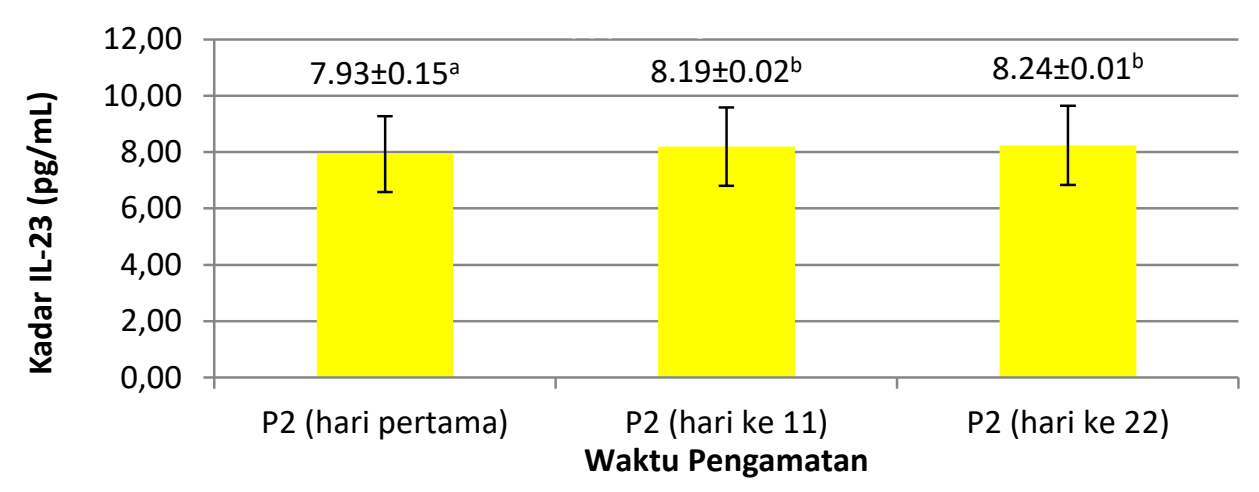

Gambar 2 Histogram rerata kadar IL-23

\section{PEMBAHASAN}

Hasil penelitian menunjukkan bahwa pemberian terapi $\mathrm{GMH}+\mathrm{AB}$ dapat meningkatkan kadar sitokin IL23 pada pengamatan di hari ke 11 dan semakin meningkat lagi pada hasil pengataman hari ke 22. Hal tersebut diatas sejalan dengan jurnal dari (Tester \& Al-Ghazzewi, 2013) bahwa Penggunaan GMH akan tampak nyata dalam mengurangi pertumbuhan dan perkembang biakan bakteri gram negative setelah pemakaian hari ke 16 .

Gardnerella vaginalis merupakan salah satu bakteri gram negative, patogen vagina paling umum yang menjadi bakteri paling banyak muncul pada Bacterial Vaginosis, kolonisasi bakteri Gardnerella vaginaslis pada selaput lendir vagina dapat meningkatkan resiko pada penderita STDs dan gagal berkembang janin serta PROM pada ibu hamil [2]. Bakteri Gardnerella vaginaslis mengeluarkan toxin yang direspon oleh sel dendritic kemudian merangsang produksi sitokin IL 6, IL 1 dan IL 23 yang semuanya akan mendorong diferensiasi sel $\mathrm{T} \mathrm{CD} 4^{+}$ ke arah sel Th $17^{1}$. Kolonisasi Gardnerella vaginalis dapat berkurang apabila factor pendukung kehidupannya terganggu, salah satunya dengan gas $\mathrm{H}_{2} \mathrm{O}_{2}$ yang diproduksi oleh bakteri Lactobacillus akan menggeser keberadaan Gardnerella vaginalis. Sehingga apabila BV belum dapat diatasi oleh Lactobacillus maka kadar IL23 tidak dapat menurun karena masih adanya sinyal terjadinya inflamasi pada mukosa vagina.

Berdasarkan pengamatan peneliti bahwa pemberian antibiotik Metronidazole dan GMH memberikan pengobatan yang maksimal dimana antibiotic Metronidazole mengurangi reaksi dari paparan pathogen kemudian GMH memiliki peran menstimulus pertumbuhan dan memberikan asupan nutrisi terhadap kelangsungan hidup Lactobacillus Vaginalis. Seperti yang dikemukakan dalam beberapa jurnal (Al- 
Ghazzewi, Elamir, Tester, \& Elzagoze, 2015) bahwa keberadaan prebiotik GMH akan meningkatkan pertumbuhan Lactobacillus yang menguntungkan. Sehingga ekosistem bakteri atau flora normal didalam vagina tetap terjaga.

\section{KESIMPULAN}

Pemberian GMH terbukti dapat menurunkan kadar sitokin IL 23 pada Bacterial Vaginosis wanita usia subur.

\section{REFERENSI}

Al-Ghazzewi, F., Elamir, A., Tester, R., \& Elzagoze, A. (2015). Effect of depolymerised konjac glucomannan on wound healing. Bioactive Carbohydrates and Dietary Fibre, 5(2), 125-128.

https://doi.org/10.1016/j.bcdf.201 5.03 .003

CDC. (2017). Bacterial Vaginosis - CDC Fact Sheet. Centers for Disease Control and Prevention, 5-6. https://doi.org/10.1016/j.carbpol.2 013.10 .092

Fethers K, Twin J, Fairley Ck, Fowkes Fj, Garland Sm, Fehler G, E. Al. (2012). Bacterial Vaginosis (BV) Candidate Bacteria: Associations With BV And Behavioural Practices In SexuallyExperienced And Inexperienced Women. Plos One, 7(2), E30633.

Guaschino S, De Santo D, D. S. F. (2002). New perspectives in antibiotic prophylaxis for obstetric and gynaecological surgery. New Perspectives in Antibiotic Prophylaxis for Obstetric and Gynaecological Surgery, 50, S13-S16.

Hay, P. (2014). Bacterial vaginosis. Medicine (United Kingdom), 42(7), 359363. https://doi.org/10.1016/j.mpmed.2 014.04.011

J, W. (2004). Managing recurrent bacterial vaginosis. Sex Transm Infect, 80, 8-11.

Leung, S., Liu, X., Fang, L., Chen, X., Guo, T., \& Zhang, J. (2010). The cytokine milieu in the interplay of pathogenic Th1/Th17 cells and regulatory $\mathrm{T}$ cells in autoimmune disease. Cellular and Molecular Immunology, 7(3), 182-189. https://doi.org/10.1038/cmi.2010.2 2

Machado, D., Castro, J., Palmeira-deOliveira, A., Martinez-de-Oliveira, J., \& Cerca, N. (2016). Bacterial vaginosis biofilms: Challenges to current therapies and emerging solutions. Frontiers in Microbiology, 6(JAN).

https://doi.org/10.3389/fmicb.201 5.01528

Ness RB, Soper DE, Holley RL, et al. (2001). Douching and endometritis: results from the PID evaluation and clinical health (PEACH) study. Sex Transm Disease. Douching and Endometritis: Results from the PID Evaluation and Clinical Health (PEACH) Study. Sex Transm Disease, 28, 240-245.

Patterson, J. L., Stull-Lane, A., Girerd, P. H., \& Jefferson, K. K. (2010). Analysis of adherence, biofilm formation and cytotoxicity suggests a greater virulence potential of Gardnerella vaginalis relative to other bacterial-vaginosis-associated anaerobes. Microbiology, 156(2), 392399.

https://doi.org/10.1099/mic.0.0342 80-0

Sutherland, A. ; R. T. ; F. A.-G. ; E. M. ; M. C. (2008). Glucomannan hydrolysate $(\mathrm{GMH})$ inhibition of Candida albicans growth in the presence of Lactobacillus and Lactococcus species. Microbial Ecology in Health and Disease, 20:3, 127 - 134. Retrieved 
from

http://dx.doi.org/10.1080/0891060 0802355726

Tester, R. F., \& Al-Ghazzewi, F. H. (2013). Mannans and health, with a special focus on glucomannans. Food Research International, 50(1), 384-391. https://doi.org/10.1016/j.foodres.2 012.10.037

Thurman, A. R., Kimble, T., Herold, B., Mesquita, P. M. M., Fichorova, R. N., Dawood, H. Y., Doncel, G. (2015). Bacterial Vaginosis and Subclinical Markers of Genital Tract Inflammation and Mucosal Immunity. AIDS Research and Human Retroviruses, 31(11), 1139-1152. https://doi.org/10.1089/aid.2015.0 006

Workowski, K., \& Levine, W. (2002). Sexually transmitted diseases treatment guidelines 2002. Centers for Disease Control and Prevention. MMWR Recomm Rep, 51(RR-6), 1-78. https://doi.org/10.1152/jn.00500.2 012

Zheng, Yan., Dimitry M., Danilenko., Patricia Valdez., Ian Kasman., Jeffrey Eastham-Anderson., J. W. \& W. O. (2007). Interleukin-22, a TH17 cytokine, mediates IL-23-induced dermal inflammation and acanthosis, Vol $445 \mid 8$. 